\title{
Skrypty nauk ścisłych w kontekście badań nad metajęzykiem
}

\section{Ida Skubis}

Politechnika Śląska w Gliwicach

i.k.skubis@gmail.com

\begin{abstract}
Streszczenie
Zdolność pisania skryptów nauk ścistych $w$ przejrzysty $i$ ciekawy sposób jest bardzo wymagajacym zadaniem, ale $w$ osiagnięciu tego celu autorowi może pomóc stosowanie licznych metatekstemów. $Z$ ich pomoca moga stworzyć artykut przyjazny odbiorcy. Te konstrukcje maja różne zastosowania, o których naukowcy często zapominaja, skupiając się przede wszystkim na przedstawieniu wyników swoich badań. Metatekstemy pomagaja autorowi m.in. w pouktadaniu i przedstawieniu ich toku myślenia, w informowaniu odbiorcy o podjętych przez autora krokach i jego opinii co do wprowadzanych informacji. Za pomoca środków metajęzykowych naukowcy moga podkreślić najważniejsze informacje $w$ tekście i powoływać się na badania innych autorów, a co najważniejsze, pomagaja one nawiąać relację $z$ czytelnikiem. Środki te maja wiele różnorodnych funkcji $i$ w niniejszym artykule prezentujemy ich role w skryptach nauk ścistych wraz z ich charakterystyka i przyktadami. Autorzy tekstów naukowych powinni zwracać więcej uwagi na język $i$ konstrukcje, których używaja w swoich tekstach, ponieważ w ten sposób wplywają na czytelnika i jego wrażenia, a także jego stosunek odnośnie do zaprezentowanych $w$ tekście danych i nas jako autora.
\end{abstract}

Słowa kluczowe: metatekstemy, metajęzyk, metaoperatory, funkcje metatekstemów, skrypty nauk ścistych

Abstract

Natural Science Textbooks in the Context of Research on Metalanguage

Ability to write Natural Science textbooks in a clear and interesting manner is a very demanding task, but the use of numerous metatextemes can help the authors to achieve it. With the application of metatextemes they can create a recipient-friendly article. These constructions have various functions, but the scientists often forget about them and concentrate mostly on showing the results of their analysis. Metatextemes help the authors e.g. to organise and present their line of thoughts, and to inform the recipient about the steps undertaken by the author and their attitude to the information they present. With the use of these metaoperators the researchers can highlight the most important information in the text and refer to research of other scientists and most of all, they help to establish a relationship with 
the reader. These measures have many different functions, and in this article we present their role in academic books on Natural Sciences with their characteristics and examples. The authors of scientific texts should pay more attention to the language and constructions they use in their texts, because in this way they influence the reader and their impressions and also their attitude towards data presented in the text and to their author.

Keywords: metatextemes, metalanguage, metaoperators, functions of metatextemes, natural science textbooks

\section{Wstęp}

Niniejszy artykuł ma na celu przedstawienie wyników z analizy skryptów nauk ścisłych pod kątem występowania w nich operatorów metatekstowych, tzw. metatekstemów. Język nauk ścisłych słynie ze swojej zwięzłości i obfitości w słownictwo specjalistyczne. Teksty nauk ścisłych skoncentrowane są głównie na opisie badań i zaprezentowaniu ich wyników, a zatem wydawać by się mogło, że zawierają nieznaczną ilość środków metajęzykowych, ponieważ są uznawane za nauki "bardzo konkretne", w przeciwieństwie do nauk humanistycznych, które znane są z obszernych opisów. W analizie fragmentów skryptów nauk ścisłych, do których wybrano skrypt $\mathrm{z}$ chemii kwantowej, biologii i biotechnologii oraz fizyki ${ }^{1}$, sprawdzano, w jakim stopniu autorzy używają metajęzyka do opisu swoich przedsięwzięć a także, który rodzaj operatorów przeważa. Aby móc analizować teksty naukowe, zaczniemy najpierw od wyjaśnienia terminu ,język naukowy”.

\section{Język naukowy}

Nauka to skomplikowany proces, w którym otrzymuje się, logicznie przepracowuje, przekazuje oraz gromadzi informacje w celu otrzymania nowych informacji (Gajda 1982: 85). Jak podkreśla Gajewska (2004: 7), każdy badacz mierzy się z dwoma głównymi zadaniami: pierwszym z nich jest zgromadzenie nowej wiedzy, a drugim jej rozpowszechnienie.

Pierwsze zadanie ma na celu znalezienie, postawienie problemu do rozwiązania, przeprowadzenie badań oraz interpretację otrzymanych rezultatów. W toku tych czynności w umyśle naukowca zachodzą intensywne procesy przepracowywania informacji, które są selekcjonowane, weryfikowane i oceniane, aby mogły doprowadzić do rozwiązania danego problemu.

\footnotetext{
${ }^{1}$ Używane skróty w pracy: chemii kwantowa (ch.k.), biologia i biotechnologii (biol.) oraz fizyka (fiz.).
} 
Drugim zadaniem badacza jest zebranie otrzymanych wyników i przemyśleń, opracowanie ich i ujęcie w formę językową, a następnie opublikowanie i rozpowszechnienie. Cytując Gajdę:

Na komunikacyjnym etapie działalności naukowej myślenie transformuje się z psychologicznego w ściśle logiczne, obiektywne, z naturalnego i dość chaotycznego w świadomie zorganizowane, z niepełnostrukturalnego w zasadniczo pełnostrukturalne i eksplicytnie wyrażone. Rezultatem tego przekształcenia jest tekst naukowy." Zatem tekst naukowy jest zbiorem ostatecznych rezultatów naukowych i analiz, wieńczy on badania i stanowi podstawowy środek komunikacji, a także środek rozpowszechniania informacji naukowych.

(Gajda 1982: 85)

Za cechę nadrzędną języka naukowego uznaje się logiczność. Logiczność w tekstach naukowych przejawia się w systematycznym, klarownym i precyzyjnym przedstawieniu informacji, w uporządkowaniu treści, w jednoznacznym formułowaniu pojęć oraz zrozumiałym ich przedstawieniu oraz w wyciąganiu logicznych wniosków. Z logicznością nieodłącznie wiąże się abstrakcyjność (pojęciowość) i ścisłość (dokładność, jednoznaczność, precyzyjność).

Gajda (1990: 37) wyróżnia cztery warianty stylu naukowego: teoretycznonaukową, którą posługują się specjaliści; popularnonaukową, mającej zastosowanie w komunikacji specjalisty z niespecjalistą; praktycznonaukową, dotyczącą sfery zastosowań nauki oraz dydaktycznonaukową, którą stosuje specjalista w komunikacji z adeptem danej specjalności.

Zanim przejdziemy do omówienia podziału i roli metatekstemów, należy przypomnieć teorię aktów mowy, których zadaniem jest przekazanie przez nadawcę komunikatu dla odbiorcy za pomocą systemu znaków językowych.

\section{Akty mowy}

Fundamenty pod teorię aktów mowy położyli brytyjscy filozofowie języka, przede wszystkim John Austin. Pośmiertnie zapiski z jego wykładów zostały opublikowane w 1962 r. w książce pt. How to Do Things with Words. Od lat sześćdziesiątych zainteresowanie teorią aktów mowy zaowocowało bogatą literaturą tworzoną przez kontynuatorów i krytyków myśli Austina. Najważniejsi z nich to: Searle, Strawson, Grice, Leech, Sadock, Wilson, Sperber i inni (Zdunkiewicz 1993: 59). Z niemieckich autorów należy wymienić takich autorów jak: Engel, Michel, Wunderlich, Gross, Erhardt, Schmidt/Harnisch. W Polsce teoria aktów mowy zaczęła 
rozwijać się w latach siedemdziesiątych, głównie za sprawą Anny Wierzbickiej oraz Krystyny Pisarkowej.

Pierwsza próba klasyfikacji aktów mowy zaproponowana przez Austina obejmowała pięć typów wypowiedzi (aktów mowy) i kierowała się głównie klasami czasowników, które wyrażają poszczególne illokucje. Są to wypowiedzi:
a) werdyktywne, np.: oceniać, szacować. zarzucać (komuś coś), uniewinniać;
b) autorytatywne, np.: nakazywać, zabraniać, ganić;
c) komisywne, np.: obiecywać,zamierzać, zobowiązywać się;
d) konduktywne, np.: dziękować, gratulować, pozdrawiać, wyrażać współczucie;
e) ekspozytywne, np.: twierdzić, zauważyć, zapewnić, zapytać.

Uczeń Austina, Searle, zaproponował również podział na pięć klas aktów mowy, jednakże kierował się on następującymi kryteriami: cel illokucyjny (illocutionary point), kierunek relacji pomiędzy słowami i światem (direction of fit) i psychiczne nastawienie mówcy (psychological state) (Lipczuk 2000: 170). Podział na akty mowy według Searle’a (1977; 1979; 1980) wygląda następująco:

a) reprezentatywy, np.: stwierdzić konstatować - mówiący przedstawia coś jako podlegające ocenie w kategoriach prawdy i fałszu;

b) komisywy, np.: obiecywać, wyrażać gotowość - mówiący określa swoją przyszłą czynność, której oczekuje słuchacz;

c) dyrektywy, np.: prosić, rozkazywać, radzić - mówiący próbuje nakłonić słuchacza do jakiego działania czy reakcji;

d) ekspresywy, np.: gratulować, usprawiedliwiać się, narzekać - mówiący wyraża swoje psychiczne nastawienie wobec treści wyrażonych w akcie propozycjonalnym;

e) deklaratywy, np.: zwalniać, uznawać za winnego, mianować, nadawać imię - poprzez wypowiedź zostają stworzone nowe fakty społeczne.

Wunderlich (1970; 1978; 1986), podobnie jak Searle (1977), Rosengren (1979) oraz Weigand (1989) wychodzą głównie od kryteriów pragmatycznych i jako podstawowe kryterium traktują miejsce danego aktu mowy w sekwencji aktów. Wunderlich (1978: 77) wyróżnia następujące akty mowy: dyrektywne, komisywne, erotetyczne (pytania), reprezentatywne, satysfaktywne, retraktywne (np. cofniecie obietnicy, korektura stwierdzenia), deklaratywne i wokatywne (np.: wywoływanie, zagadywanie kogoś). 


\subsection{Składniki aktów mowy}

Austin (za Großem 1998: 159) wyróżnił trzy aspekty aktów mowy:

a) aspekt lokucyjny - odnosi się do procesu tworzenia, na mocy kodu językowego, określonego wyrażenia o treści wynikającej z systemu języka;

b) aspekt illokucyjny - wiąże się z naszymi intencjami, tym, co chcemy osiągnąć za pomocą danego wypowiedzenia, np. prośba, ostrzeżenie, obietnica, groźba itd. Wartość illokucji mierzona jest w kategorii skuteczności;

c) aspekt perlokucyjny - jest związany z rezultatami aktu komunikacyjnego. Efektami perlokucyjnymi mogą być zatem: zlekceważenie, obraza, skomplementowanie, rozbawienie oraz inne zmiany mentalne i emocjonalne wywołane u odbiorcy

Jak widać na podstawie klasyfikacji aktów mowy, każda wypowiedź niesie za sobą jakieś przesłanie i ma określony cel. Tak też jest w przypadku metatekstemów, które zależnie od intencji autora mają określone zadanie $\mathrm{w}$ tekstach naukowych. Metakomunikacja to komunikacja traktująca o procesach komunikacji (Leclerc 1999: 232). Według Lüdke (1984: 19) nadawca wypowiedzi odnosi się do jej treści i sensu, uwzględniając fakt, że jest w trakcie interakcji z innymi uczestnikami swojej wypowiedzi. Do metakomunikacji zaliczamy także komunikację niewerbalną, taką jak: gesty, mimika, kontekst czy sytuacja. Metajęzyk natomiast to język służący do opisu jakiegoś innego języka.

W metakomunikacji używa się metatekstemów. Są to operatory syntaktyczne wykorzystywane do budowania relacji między nadawcą a odbiorcą, a w tekstach naukowych między autorem a czytelnikiem. Służą one do organizacji tekstu, m.in. wprowadzają temat, sygnalizują jego zmianę, informują o przerwaniu czy kontynuowaniu rozważań naukowych. Ich głównym zadaniem jest przekazanie treści w najbardziej klarowny dla odbiorcy sposób. W Polsce obszerną klasyfikację metatekstemów zaproponowały dwie badaczki: Urszula Gajewska (2014), która zademonstrowała podział operatorów w języku nauk ścisłych oraz Danuta Olszewska (2007) prezentująca klasyfikację dla nauk humanistycznych. Dla celów niniejszego artykułu bazujemy na podziale zaproponowanym przez Urszulę Gajewską, ponieważ badamy skrypty nauk ścisłych, dostosowując go do potrzeb niniejszego artykułu.

\subsection{Podział metatekstemów według Urszuli Gajewskiej}

Gajewska (1999: 37) wyróżnia sześć głównych grup metatekstemów:

1. metatekstemy wskazujące na relacje intertekstualne;

2. metatekstemy wskazujące na relacje wewnątrztekstowe; 
3. metatekstemy akcentujące przebieg rozumowania;

4. metatekstemy wprowadzające przeformułowanie;

5. metatekstemy charakteryzujące wprowadzane treści pod względem epistemicznym;

6. metatekstemy podkreślające ważność wprowadzanych informacji.

Poniżej przedstawiamy opis najważniejszych cech każdej grupy i jej dalszy podział.

1. metatekstemy wskazujące na relacje intertekstualne

Badaczka definiuje tę grupę jako:

(...) metatekstowe konstrukcje syntaktyczne, za pomocą których nadawca odsyła odbiorcę do innych tekstów.

(Gajewska 1999: 34)

Gajewska posługuje się tutaj pojęciem intertekstualności, którą definiuje następująco:

Intertekstualnością nazywać będziemy wszelkie sposoby odwoływania się do nadawcy wypowiedzi do wcześniejszych tekstów, do wiedzy w nich zawartej.

(Gajewska 1999: 35)

Jak podkreśla badaczka, relacje intertekstualne występują licznie i odgrywają istotną rolę w tekstach naukowych, ponieważ autor konfrontuje swoje wyniki nie tylko z badanymi aktualnie zjawiskami, lecz także z wyjaśnianiem tych zjawisk w dotychczasowej literaturze, bazując na wiedzy swoich poprzedników oraz porównując swoje wyniki z wynikami innych autorów.

Za pomocą metatekstemów intertekstualnych nadawca wypowiedzi odsyła do kontekstu komunikacyjnego oraz przywołuje pewne treści z literatury przedmiotu.

W celu przytoczenia „cudzej mowy”, w tekstach naukowych stosuje się często mowę zależną, aby uniknąć wielokrotnego wprowadzania cytatów.

W grupie metatekstemów intertekstualnych badaczka wyróżnia następujące kategorie:

1.1. metatekstemy wprowadzające przytoczenie.

Przytoczeniem określane są tu wszelkie sposoby wprowadzania do tekstu „cudzej mowy”, za pomocą mowy zależnej lub niezależnej. Tę grupę można podzielić na kolejne podkategorie:

1.1.1. ze wskazanym imiennie autorem przekazywanych treści;

1.1.2. z nieoznaczonym autorem wprowadzanych informacji;

1.1.3. z nieoznaczonym autorem wprowadzanych informacji, wskazujące na powszechną znajomość przywoływanych informacji;

1.2. metatekstemy wprowadzające wnioski wypływające z kontekstu komunikacyjnego; 
1.3. metatekstemy ustalające/przywołujące wspólną wiedzę nadawcy i odbiorcy;

1.4. metatekstemy odsyłające do kontekstu komunikacyjnego.

2. metatekstemy wskazujące na relacje wewnątrztekstowe:

Metatekstemy te służą do wyodrębnienia poszczególnych części tekstu, tzn. oddzielenia początku i końca od głównej części, tworząc tzw. „ramy”. Jak podkreśla Dobrzyńska (1991) ustanowienie ram ma podstawowe znaczenie dla przebiegu komunikacji. Danek (1972) akcentuje, że w granicznych miejscach tekstu, zwłaszcza na jego początku, czyli we wstępie, przedmowie, widoczna jest obecność metatekstemów.

Metatekstemy wewnątrztekstowe służą do wydzielenia ram w obrębie tekstu i do tej grupy zaliczamy:

2.1. metatekstemy w funkcji odgraniczającej:

2.1.1. metatekstemy funkcjonujące $\mathrm{w}$ części inicjalnej tekstu;

2.1.2. metatekstemy funkcjonujące w części finalnej tekstu;

2.2. metatekstemy wskazujące na relacje w ciągu linearnym - anaforyczne i kataforyczne;

2.2.1. metatekstemy retrospektywne;

2.2.2. metatekstemy progresywne.

ad.2.1. metatekstemy $w$ funkcji odgraniczającej

Do tej grupy zalicza się metatekstemy, które oddzielają początek i koniec od reszty tekstu (rozwinięcia). Gajewska (2004: 53) dzieli tę grupę na dwie podkategorie:

a.d.2.1.1. metatekstemy funkcjonujące w części inicjalnej tekstu

Za pomocą metatekstemów występujących w inicjalnej części pracy autor oznajmia, jaką problematyką będzie się zajmował. Podaje i wyjaśnia temat swojej pracy i rozdziałów.

Na początku nadawca tekstu może nadmienić, że pojęcie lub temat jest mało znany lub był wcześniej niedostatecznie zanalizowany. Autor jest w stanie także zasygnalizować, że temat jest już dobrze znany i był analizowany przez innych naukowców.

ad.2.1.2. metatekstemy funkcjonujące w części finalnej tekstu

W części końcowej autor streszcza swoją pracę i wyciąga wnioski, dlatego w tej grupie możemy wyróżnić dwie podgrupy (za Gajewską 2004: 71):

2.1.1.1. metatekstemy funkcjonujące $\mathrm{w}$ zakończeniach $\mathrm{w}$ formie streszczenia.

2.1.1.2. metatekstemy funkcjonujące $\mathrm{w}$ zakończeniach o postaci konkluzji.

a.d.2.2. metatekstemy wskazujące na relacje w ciągu linearnym - anaforyczne i kataforyczne 
Autor odnosi się do wcześniejszych treści swojego tekstu lub do treści, które pojawią się dopiero w dalszym etapie publikacji, dlatego wyróżnia się tutaj dwie podgrupy:

a.d. 2.2.1. metatekstemy regresywne

Metatekstemy regresywne wskazują na relacje wstecz po linii tekstu (anafora), czyli odnoszą się do już wspomnianych wcześniej informacji.

a.d.2.2.2. metatekstemy progresywne

Metatekstemy progresywne służą do zapowiadania treści, które pojawią się w kolejnych etapach tekstu (katafora).

3. metatekstemy akcentujące przebieg rozumowania

Metatekstemy akcentujące przebieg rozumowania mają na celu wyjaśnienie poszczególnych etapów w tekście oraz przebieg naukowego rozważania. Najistotniejsze komponenty, jakie można wyróżnić w tej grupie to: sformułowanie problemu, przyjęcie założeń, uzasadnienie twierdzeń, wyciąganie wniosków. Ich kluczową cechą jest ułatwienie zrozumienia struktury tekstu dla odbiorcy.

Gajewska (2004: 85) wyróżnia następujące metatekstemy w tej grupie:

3.1. metatekstemy sygnalizujące problem aktualnych rozważań;

3.2. metatekstemy sygnalizujące wprowadzanie założeń;

3.3. metatekstemy wprowadzające efekty badań i rozważań;

3.3.1. metatekstemy sygnalizujące wnioskowanie;

3.3.2. metatekstemy wprowadzające rezultaty badań doświadczalnych;

3.3.3. metatekstemy sygnalizujące wprowadzanie stwierdzeń.

a.d.3.1. metatekstemy sygnalizujące problem aktualnych rozważań

Za pomocą tych metatekstemów autor akcentuje szczególnie ważne treści w swojej pracy, takie jak sformułowanie problemu, który będzie analizowany w dalszej części pracy oraz rozpoczęcie lub kontynuacja jego rozwiązywania. Metatekstemy te nie występują we wstępie, lecz w głównej części tekstu.

a.d.3.2. metatekstemy sygnalizujące wprowadzanie założeń

W tekstach naukowych często istotnym elementem jest przyjmowanie założeń, które mają autorowi ułatwić przebieg rozważań oraz stanowią ich punkt wyjścia.

a.d.3.3. metatekstemy wprowadzające efekty badań i rozważań Autor używa tych konstrukcji w celu wprowadzenia efektów dotychczasowych rozważań i przeprowadzonych badań. Do tej grupy zalicza się następujące metatekstemy:

a.d.3.3.1. metatekstemy sygnalizujące wnioskowanie 
Za pośrednictwem tych metaoperatorów autor informuje odbiorcę, że wprowadzane treści stanowią wnioski z określonych przesłanek i wcześniej przeprowadzonych badań.

a.d.3.3.2. metatekstemy wprowadzające rezultaty badań doświadczalnych

Konstrukcje te służą do przedstawienia wyników z przeprowadzonych wcześniej doświadczeń lub eksperymentów.

a.d.3.3.3. metatekstemy sygnalizujące wprowadzanie stwierdzeń

Za pomocą tych metaoperatorów nadawca dokonuje aktu stwierdzania. Jak podkreśla GizbertStudnicki (1973: 93), w ten sposób bierze on odpowiedzialność za prawdziwość swoich wypowiedzi. W tej grupie często stosowane są takie czasowniki jak stwierdzić, powiedzieć.

4. metatekstemy wprowadzające przeformułowanie

Czwarty rodzaj metatekstemów to metatekstemy wprowadzające przeformułowanie.

Przeformułowanie można wyjaśnić za pomocą następującego cytatu:

Przeformułowaniem nazywa się stwierdzenie równoważności w dyskursie (zrelatywizowanie do sytuacji wypowiadania, a zwłaszcza do komunikacyjnych celów rozmówców) bądź organizowanie wypowiedzi z uwagi na interpretację odbiorcy.

(Gajewska 2004: 160)

Jak pokazuje powyższy cytat, przeformułowanie to językowy proces parafrazowania wcześniejszej wypowiedzi.

Gajewska (2004: 160) dzieli tę grupę następująco:

4.1. metatekstemy wprowadzające wypowiedź tożsamą znaczeniowo lub zbliżoną do treści wypowiedzi podlegającej parafrazowaniu

4.2. metatekstemy wprowadzające uogólnienie

4.3. metatekstemy wprowadzające uszczegółowienie

4.4. metatekstemy wprowadzające wyjaśnienie

a.d.4.1. metatekstemy wprowadzające wypowiedź tożsamą znaczeniowo lub zbliżoną do treści wypowiedzi podlegającej parafrazowaniu.

Zadaniem tych konstrukcji jest parafrazowanie wypowiedzi, czyli wprowadzenie treści bliskoznacznej do wypowiedzi źródłowej. Autor wyraża tę samą myśl, ale używając innych słów, aby ułatwić odbiorcy zrozumienie treści.

a.d.4.2. metatekstemy wprowadzające uogólnienie 
Stanowią one najliczniejszą i nabardziej zróżnicowaną grupę wśród mateoperatorów wprowadzających przeformułowanie. Tworzone są za pośrednictwem czasownika mówić, imiesłowu uogólniając i leksemu ogólny ulegającemu stopniowaniu.

a.d.4.3. metatekstemy wprowadzające uszczegółowienie

W przeciwieństwie do poprzedniej podgrupy, konstrukcje te pozwalają autorowi na doprecyzowanie i uściślenie wcześniej podanych informacji.

a.d.4.4 metatekstemy wprowadzające wyjaśnienie

Służą one do wprowadzania wyjaśnienia danego zjawiska, wniosku, stwierdzenia, założenia, faktu czy pojęcia.

5. metatekstemy charakteryzujące wprowadzane treści pod względem epistemicznym Gajewska (2004: 183) wspomina tutaj o pojęciu modalności i jej odmiany, jednakże koncentruje się ona na modalności epistemicznej, która odnosi się do wiedzy i zarządza pojęciami pewności, prawdopodobieństwa, przypuszczenia, nieprawdopodobieństwa, wątpienia i niepewności. Jest ona odzwierciedleniem stanowiska nadawcy względem prawdziwości lub fałszywości jego wypowiedzi. Można wydzielić dwie grupy:

5.1. metatekstemy o modalnej funkcji pewności;

5.2. metatekstemy o modalnej funkcji możliwości.

a.d.5.1. metatekstemy o modalnej funkcji pewności

Autor wyraża za ich pośrednictwem swoją pewność w kwestii prawdziwości przedstawionych przez niego informacji, a pewność ta wypływa z posiadanej przez niego wiedzy.

a.d.5.2. metatekstemy o modalnej funkcji możliwości

Użycie konstrukcji syntaktycznych o modalnej funkcji możliwości świadczy o niepełnym przekonaniu autora co do prawdziwości przekazywanych treści. W ten sposób sugeruje on odbiorcy, że tylko przypuszcza, a nie ma pewności, że informacje są zgodne z rzeczywistością.

6. metatekstemy podkreślające ważność wprowadzanych informacji

Ostatnią grupę metatekstemów stanowią metaoperatory, które mają za zadanie zasygnalizowanie i podkreślenie, że dane informacje wprowadzane przez nadawcę są ważne. Jest to jego subiektywna ocena, podbudowana teoretyczną i praktyczną wiedzą, decydująca o tym, które informacje należy uznać za istotne i na które odbiorca powinien zwrócić szczególną uwagę.

Gajewska (2004: 183) zaproponowała dogłębną i obszerną analizę operatorów metatekstowych, dzięki czemu możemy lepiej zrozumieć ich znaczenie i funkcje. W analizie 
skryptów nauk ścisłych posłużymy się jej klasyfikacją, dostosowując ją do potrzeb niniejszych badań. Jak już wcześniej zostało wspomniane, analizowaliśmy fragmenty skryptów z chemii kwantowej, biologii oraz fizyki pod kątem obecności w niech metatekstemów oraz sprawdzenia, które z tych środków pojawiają się najczęściej. Wyniki prezentujemy poniżej.

\section{Metatekstemy w skryptach nauk ścisłych (chemii kwantowej, biologii oraz fizyce)}

1. Metatekstemy intertekstualne

W tej grupie znalazły się metatekstemy odnoszące się do dzieł i wyników innych autorów, a także metatekstemy odwołujące do wspólnej wiedzy nadawcy z odbiorcą, np.:

Jednakże często stosować będziemy notację Leibniza [...]. s. 11 (ch.k.)

Bohr oparł swój model atomu na modelu planetarnym Rutherforda. Podstawowe założenia modelu Bohra [...]. s. 31 (ch.k.)

W myśl wzoru Rayleigha-Jeansa energia na jednostkę objętości wynosi [...]. s. 30 (ch.k.)

Jak pamiętamy, różniczka funkcji jednej zmiennej dana jest zależnością s. 18 (ch.k.)

Dzięki pracom A. I. Oparina, J. B. S. Haldane'a, a potem S. L. Millera oraz H. C. Urey’a oraz S. W. Foxa wiadomo, że [...]. s. 19 (biol.)

Obecnie funkcjonującą organellarną teorię endosymbiontyczną zaproponowała L. Margulis w roku 1966 (rozwinięcie obserwacji A. Schimpera i K. Mereszkowskiego). s. 23 (biol.)

Uważa się, że mitochondria powstały z bakterii tlenowych [...]. s. 23 (biol.)

Opisał on m.in. cykl mocznikowy, zależności między oddychaniem a syntezą [...]. s. 37 (biol.)

Uważa się, że bezpośrednim sygnałem apoptozy jest TNF [...]. s. 44 (biol.)

Matematycy definiują pojęcie pochodnej funkcji f(x) w punkcie x [...]. s. 10 (fiz.)

2. Metatekstemy wewnątrztekstowe:

Znajdują się tu zarówno metatekstemy w funkcji odgraniczącej ramy tekstu, a także metatekstemy retrospektywne, odsyłające do wcześniejszych informacji w tekście oraz metatekstemy progresywne nawiązujące do wiadomości przedstawionych w kolejnych częściach pracy, np.: 
$\mathrm{Na}$ rysunku 1.1 przedstawiono geometryczną interpretację liczby zespolonej [...]. s. 5 (ch.k.)

W tab. 1.1 przedstawiono [...]. s. 8 (ch.k.)

W definicji (1.56) zastosowaliśmy symbol pochodnej Lagrange'a. s. 11 (ch.k.)

W dalszej części wektor zmiennych (1.132) będziemy oznaczać jako r [...]. s. 18 (ch.k.)

Dla tego ostatniego przypadku jako bazę możemy wybrać np. wersory osi [...]. s. 23 (ch.k.)

Wykresy funkcji falowych dla $n \in\{1 ; 2 ; 3 ; 4\}$ przedstawiono na rysunku 3.2. s. 48 (ch.k.)

Na rysunkach 3.3-3.8 przedstawiono wykresy funkcji falowych dla kilku stanów. s. 50 (ch.k.)

W tabeli 1.3 zestawiono pochodne najważniejszych funkcji. s. 13 (ch.k.)

Pojęcie iloczynu skalarnego uogólnimy w rozdziale 1.4.2. s. 18 (ch.k.)

Jak wykazano w ćwiczeniu 2.9, jest to spełnione wówczas, gdy funkcja [...] s. 39 (ch.k.)

Jak opisano wcześniej, niektóre związki chemiczne [...]. s. 19 (biol.)

Atomy wymienionych wcześniej pierwiastków na ogół nie występują w organizmach w stanie wolnym. s. 10 (biol.)

Dokładny opis budowy i funkcjonowania organelli (ryc. 5) stanowi przedmiot zainteresowania histologii [...] s. 22 (biol.)

Kwasy nukleinowe zostaną omówione w części poświęconej genetyce, w rozdziale [...]. s. 19 (biol.)

Dokładniej procesy te zostaną omówione w rozdziale dotyczącym metabolizmu komórkowego [...]. s. 24 (biol.)

Ich funkcje zostaną pokrótce przedstawione $\mathrm{w}$ rozdziale dotyczącym metabolizmu komórkowego [...]. s. 24 (biol.)

Wybrane aspekty budowy i funkcjonowania tych układów będą omawiane jako przykłady mechanizmów kontrolujących funkcjonowanie organizmu. s. 32 (biol.)

Jak opisano w rozdziale o potencjale czynnościowym komórki nerwowej [...]. s. 45 (biol.) W pierwszym rozdziale przedstawiamy podstawowe informacje [...]. s. 8 (fiz.)

Powyższe równanie należy dodatkowo nazwać układem równań liniowych [...]. s. 8 (fiz.) Metod rozwiązywania układów równań jest przynajmniej kilka, np. powyższe równanie (1.1.) można by rozwijać wyznaczając $\mathrm{x}$ z pierwszego równania i podstawiając do drugiego. s. 8 (fiz.)

[...] nie każde równanie warto rozwiązywać jedną z dwóch powyższych metod. s. 8 (fiz.) W sekcji Przykłady poniżej pokażemy też jak stosować te wzory [...]. s. 11 (fiz.)

Na Rysunku 1.2. widać, że taka konstrukcja jest równoważna [...] s. 13 (fiz.) 
Korzystając z powyższej definicji (1.24.) można obliczyć każdą całkę [...]. s. 22 (fiz.)

Podamy tutaj tylko dwie najważniejsze, choć nie będziemy później z nich korzystać w dalszej części skryptu. s. 20 (fiz.)

Tak jak wspominaliśmy, układ odniesienia może być wybrany dowolnie [...]. s. 15 (fiz.)

Skoro już wspomnieliśmy o wyborze układu współrzędnych [...]. s. 14 (fiz.)

3. Metatekstemy sygnalizujące przebieg rozumowania

W tej grupie wyróżniliśmy metatekstemy sygnalizujące problem aktualnych rozważań, do których dołączyliśmy także metatekstemy opisujące kroki podejmowane przez autora. Grupa ta obejmuje również metatekstemy sygnalizujące wprowadzanie założeń oraz efektów badań, przede wszystkim dotyczących wniosków i stwierdzeń, np.:

3.1 metatekstemy sygnalizujące problem aktualnych rozważań:

Najpierw rozwijamy nieznaną funkcję [...]. s. 122 (ch.k.)

Ostatecznie mamy więc dwie możliwości [...]. s. 41 (ch.k.)

Najpierw wprowadzimy wektor zmiennych [...]. s. 17 (ch.k.)

Z kolei dla własności (4) zgodnie z (1.56) uzyskujemy. s. 12 (ch.k.)

Ostatecznie, pochodna k-tego rzędu funkcji [...]. s. 14 (ch.k.)

Nie omawiamy tu fotosyntezy dokładnie, pominiemy również warianty C3 i C4; chodzi tylko o nabranie wyobrażenia, skąd pochodzą związki organiczne [...]. s. 36 (biol.)

Najpierw po połączeniu [...], potem przez przyłączenie [...]. s. 8 (biol.)

Nie jest naszym celem ćwiczenie rozwiązywania układów równań. s. 8 (fiz.)

$\mathrm{Na}$ koniec zastanowimy się nad rozwiązaniem układu równań [...]. s. 9 (fiz.)

W ostatnim kroku przenieśliśmy 2 z licznika do mianownika. s. 11 (fiz.)

Nie będziemy tutaj wchodzić w szczegóły, ale [...]. s. 21 (fiz.)

Nie będziemy się tym więcej zajmować, ale powiemy sobie tylko, że [...]. s. 19 (fiz.)

Podamy tutaj tylko dwie najważniejsze, choć nie będziemy później z nich korzystać w dalszej części skryptu. s. 20 (fiz.)

Nie jest naszą intencją, aby wyłożyć tutaj kompletną teorię rachunku całkowego, ani nawet podać precyzyjne definicje i twierdzenia. s. 18 (fiz.)

[...] Dlatego podamy tutaj najważniejsze informacje dot. rachunku całkowego i przedstawimy jego proste zastosowania w życiu. s. 18 (fiz.)

Zacznijmy więc od podstawowych informacji dot. całek nieoznaczonych. s. 18 (fiz.)

Łatwo sprawdzamy, że [...]. s. 9 (ch.k.) 
Sprawdźmy, że własność (2) istotnie wynika z definicji [...]. s. 12 (ch.k.)

Zajmiemy się obecnie rozwinięciem funkcji f(x) wokół danego punktu x0 $\in$ Df. s. 14 (ch.k)

Musimy znaleźć wyrażenie na współczynniki an tego rozwinięcia. s. 14 (ch.k.)

Obliczmy kolejne pochodne funkcji. s. 14 (ch.k.)

Teraz już łatwo możemy obliczyć całki. s. 16 (ch.k.)

Obecnie rozpatrzymy funkcje zależne od wielu zmiennych. s. 19 (ch.k.)

Rozważymy obecnie wektorową funkcję wielu zmiennych $\mathrm{f}(\mathrm{r}) \in \mathrm{R}$ n. s. 22 (ch.k.)

Rozważmy dwie funkcje własne operatora hermitowskiego A^^s. 38 (ch.k.)

Dla uproszczenia rozpatrujmy w dalszym ciągu układ złożony z jednej cząstki. s. 36 (ch.k.)

Rozpatrzmy zagadnienie własne operatora A^. s. 37 (ch.k.)

Ostatnią właściwością wody, o której wspomnimy w tym miejscu [...]. s. 12 (biol.)

[...] tutaj zamieszczone zostanie tylko krótkie zestawienie najważniejszych ich cech, konieczne dla późniejszego zrozumienia funkcjonowania [...]. s. 22 (biol.)

Biorąc pod uwagę kierunek działania tych sił, można się domyślać, że [...]. s. 49 (biol.)

[...]. Biorąc pod uwagę charakter takiego cyklu - jego substraty i produkty - uważa się go za bardzo interesujący w badaniach powstawania życia na Ziemi. s. 38 (biol.)

Dla przykładu, zastanówmy się nad granicą funkcji tangens w punkcie x0. s. 10 (fiz.)

Sposób obliczania granicy ilorazu różnicowego, czyli znajdowania pochodnej funkcji w punkcie, opiszemy na dwóch przykładach. s. 10 (fiz.)

Obliczmy pochodną funkcji $\mathrm{f}(\mathrm{x})=\mathrm{x} 2$ korzystając $\mathrm{z}$ definicji pochodnej. s. 11 (fiz.)

Teraz znajdźmy pochodną funkcji $\mathrm{f}(\mathrm{x})=\sin \mathrm{x}$. s. 11 (fiz.)

Wykorzystamy teraz wzór trygonometryczny na równań sinusów[...]. s. 11 (fiz.)

Teraz zastanowimy się nad geometryczną interpretacją pochodnej funkcji. s. 12 (fiz.)

Zapiszmy definicję metody, którą łatwo zrozumiemy na prostym przykładzie. s. 20 (fiz.)

Zacznijmy więc od podstawowych informacji dot. całek nieoznaczonych. s. 18 (fiz.)

Sprawdźmy, czy są wśród nich pary wektorów prostopadłych. s. 17 (fiz.)

Teraz znajdziemy iloczyn wektorowy $\sim \mathrm{a} \times \sim \mathrm{b}$ wg wzoru [...]. s. 17 (fiz.)

W tym miejscu chcemy omówić bardzo ważną z punktu widzenia dalszej części opracowania kwestię. s. 15 (fiz.)

[...] to wprowadźmy matematyczny opis wektora jako zestaw liczb określających jego współrzędne. s. 14 (fiz.)

3.2. metatekstemy sygnalizujące założenia 
Zauważmy, że dana liczba zespolona z 6=0 ma nieskończenie wiele argumentów[...], stąd przyjmuje się, że [...]. s. 6 (ch.k.)

Przyjmujemy ponadto, że pierwsza permutacja jest zawsze identycznościowa [...]. s. 8 (ch.k.)

Przyjmujemy konwencję, że jeśli antysymetryzator [...]. s. 9 (ch.k.)

Załóżmy, że funkcję f można rozwinąć w nieskończony szereg potęgow [...]. s. 14 (ch.k.)

Załóżmy, że funkcja f(r) wyrażona jest we współrzędnych sferycznych [...]. s. 20 (ch.k.)

Przyjmując na przykład $\beta 1=1, \gamma 2=-15$ i $\gamma 3=5$ otrzymujemy. s. 28 (ch.k.)

Załóżmy, że wszystkie wartości własne obu operatorów są niezdegenerowane. s. 38 (ch.k.)

[...]a ponieważ założyliśmy, że obie wartości własne są różne [...]. s. 38 (ch.k.)

Przyjmuje się, że pierwsze pierwiastki powstały, kiedy Wszechświat [...]. s. 8 (biol.)

Postuluje się możliwość, że życie powstało poza Ziemią, np. na Marsie [...]. s. 19 (biol.)

Zakłada się, że wielokomórkowość mogła być efektem ścisłej symbiozy [...]. s. 26 (biol.)

Przyjmujemy, że kąt między wektorami wynosi $\alpha$. s. 16 (fiz.)

3.3. metatekstemy sygnalizujące efekty badań i rozważań: wnioskowanie, oraz rezultaty badań Jak łatwo zauważyć, zachodzi relacja s. 5 (ch.k.)

Tak więc rozwinięcie (1.87) ma postać [...] s. 14 (ch.k.)

[...] zaś z uwagi na parzystosć funkcji podcałkowej otrzymujemy od razu. s. 16 (ch.k.)

Zauważmy, że [...] skąd otrzymujemy bardzo ważną zależnosć: D = P -1AP. s. 29 (ch.k.)

Zatem macierze operatorów odbicia, obrotu w trójwymiarowym układzie [...]. s. 27 (ch.k.)

Przyjmując na przykład $\beta 1=1, \gamma 2=-15$ i $\gamma 3=5$ otrzymujemy [...]. s. 28 (ch.k.)

Rozumując analogicznie jak w przypadku dwuwymiarowym dochodzimy do wniosku, że funkcja falowa cząstki nie znika tylko w obszarze A. s. 50 (ch.k.)

$\mathrm{Z}$ równania (3.42) wynika, że funkcja |ni nie jest funkcją własną operatora pędu. s. 49 (ch.k.)

Z równań (2.92) i (2.93) wynika, że liczbę $\mid$ ck 2 można interpretować jako prawdopodobieństwo, że w wyniku pomiaru wielkości A otrzymamy wartość [...] s. 40 (ch.k.)

Z układu równań (2.84) wynika, że [...]. s. 39 (ch.k.)

[...] zatem w ogólności zachodzi [A^; $\left.\mathrm{B}^{\wedge}\right]$ [...]. s. 39 (ch.k.)

Zatem, aby zapewnić korzystniejszy rozkład sił wiązań wodorowych [...]. s. 12 (biol.)

Jest to przyczyną paradoksalnego zjawiska polegającego na tym, że [...] s. 12 (biol.) 
[...]obu siatkówek minimalnie się różni, co pozwala na ocenę głębi i odległości. s. 47 (biol.)

Biorąc pod uwagę kierunek działania tych sił, można się domyślać, że [...]. s. 49 (biol.)

Można zauważyć, że przenosząc $\mathrm{w}$ drugim równaniu 2x na drugą stronę znaku równości dostaniemy $2 x+8$, czyli $2(x+4)$. s. 8 (fiz.)

Ciekawy wniosek wypływa z warunku zerowania się pochodnej [...]. s. 12 (fiz.)

Widzimy więc, że wektory $\sim \mathrm{a}$ i c są prostopadłe. s. 17 (fiz.)

Zauważmy, że dana liczba zespolona z $6=0$ ma nieskończenie wiele [...]. s. 6 (ch.k.)

Widzimy też, że z warunku idempotentności antysymetryzatora [...]. s. 10 (ch.k.)

[...] widzimy więc, że po [...] otrzymujemy [...]. s. 14 (ch.k.)

[...] równanie (3.48) można przedstawić w postaci. s. 50 (ch.k.)

Otrzymano m. in. wszystkie aminokwasy oraz zasady azotowe [...]. s. 9 (biol.)

$[\ldots]$ jeżeli w ilorazie wprost wstawimy $\mathrm{x}=\mathrm{x} 0$, to dostaniemy wyrażenie $00[\ldots] . \mathrm{s} .10$ (fiz.)

Dostaliśmy w wyniku taką samą całkę, jak wyjściowa. s. 21 (fiz.)

4. Metatekstemy sygnalizujące przeformułowanie Metatekstemy znajdujące się $\mathrm{W}$ tej grupie dotyczą parafrazowania, uogólniania, uszczegółowiania oraz wyjaśnień, np.:

Pojęcie iloczynu skalarnego uogólnimy w rozdziale 1.4.2. s. 18 (ch.k.)

W ogólności, poza pewnymi patologicznymi przypadkami [...]. s. 18 (ch.k.)

Działanie gradientu (1.139) na funkcję f(r) możemy wyrazić w postaci [...]. s. 20 (ch.k.)

W analogiczny sposób można zdefiniować przestrzeń [...]. s. 23 (ch.k.)

Oznacza to, że w sumie (4.22) znika człon dla [...] s. 21 (ch.k.)

Rozumując analogicznie jak w przypadku dwuwymiarowym dochodzimy do wniosku, że funkcja falowa cząstki nie znika tylko w obszarze A. s. 50 (ch.k.)

$\mathrm{Z}$ równań (2.92) i (2.93) wynika, że liczbę $|\mathrm{ck}| 2$ można interpretować jako prawdopodobieństwo [...]. s. 40 (ch.k.)

Dla uproszczenia rozpatrujmy w dalszym ciągu układ złożony z jednej cząstki. s. 36 (ch.k.)

Oznacza to, że aby podgrzać np. kilogram wody o $1{ }^{\circ} \mathrm{C}$ trzeba [...]. s. 12 (biol.)

W uproszczeniu można to sobie wyobrazić następująco: [...]. s. 25 (biol.)

Ze względu na morfologię, czyli kształt komórek, wyróżnić można nabłonki [...]. s. 29 (biol.) 
Na przykład uzasadnione było wyspecjalizowanie grup komórek [...]. s. 30 (biol.)

U kręgowców ogólnie można wyróżnić układy: nerwowy, ruchu [...]. s. 30 (biol.)

Układ pokarmowy można traktować jako część zewnętrznej powierzchni [...]. s. 31 (biol.)

W skład układu pokarmowego człowieka wchodzą: jama ustna, gardło, [...]. s. 31 (biol.)

[...]. Na przykład, jeśli temperatura wzrasta o $1 / 10^{\circ} \mathrm{C}$ [...]. s. 33 (biol.)

[...]. Na przykład, w komórkach układu rozrusznikowego serca [...]. s. 50 (biol.)

Wyróżnia się telereceptory [...], eksteroreceptory [...]. s. 46 (biol.)

Wyróżnić można pięć podstawowych faz: G0, G1, S, G2, M. s. 39 (biol.)

Wyróżnić w niej można dwa kolejne podziały, obydwa z profazą, metafazą [...]. s. 42 (biol.)

Na przykład, w czasie rozwoju embrionalnego jest częścią kształtowania ciała [...]. s. 44 (biol.)

W ten sposób otrzymamy jedno równanie na jedną niewiadomą y. s. 8 (fiz.)

Tak na marginesie, rozwiązaniem układu (1.1.) jest para $x=y=2 . s .8$ (fiz.)

Generalnie, często warto szukać wzoru skróconego mnożenia w równaniach. s. 9 (fiz.)

Ta sytuacja z kolei oznacza, że funkcja ma w tym punkcie [...]. s. 12 (fiz.)

Najprościej można powiedzieć, że jest do odcinek zorientowany w przestrzeni [...]. s. 13 (fiz.)

Drugi przykład jest może nieco mniej oczywisty, bo [...]. s. 21 (fiz.)

Tutaj wyjaśnia się też, dlaczego w definicji (1.19.) potrzebna jest stała const [...]. s. 18 (fiz.)

Zacznijmy więc od podstawowych informacji dot. całek nieoznaczonych. W tym sensie powiemy, że całka (nieoznaczona) jest funkcją s. 18 (fiz.)

Oznacza to tylko tyle, że wektory w iloczynie wektorowym [...]. s. 17 (fiz.)

Dla prostoty zajmiemy się wektorami na płaszczyźnie, co łatwo uogólnimy na trzy wymiary [...]. s. 14 (fiz.)

W ogólnym przypadku możemy sobie wyobrazić, że zarówno początek jak i koniec [...]. s. 14 (fiz.)

5. Metatekstemy o modalnej funkcji pewności i możliwości:

Tę grupę reprezentują metatekstemy o modalnej funkcji pewności lub możliwości, dzięki którym autor wyraża swoje przekonanie co do prawdziwości podawanych twierdzeń lub swoich wątpliwości, a także osądza, czy dany stan rzeczy jest prawdopodobny i możliwy, np.: 
Co oczywiste, podwójne działanie operatorem permutacji par nie zmienia ciągu [...]. s. 8 (ch.k.)

Oczywiście dla danej funkcji f możemy obliczać kolejne pochodne [...]. s. 13 (ch.k.)

Możemy oczywiście obliczać pochodne wyższych rzędów [...]. s. 18 (ch.k.)

Parametrem jest tutaj oczywiście czas, zaś prędkość i przyspieszenie [...]. s. 21 (ch.k.)

Co oczywiste, baza takiej przestrzeni zawiera nieskończenie wiele elementów [...]. s. 24 (ch.k.)

[...] energia na jednostkę objętości wynosi [...] co jest oczywistym absurdem [...]. s. 30 (ch.k.)

Oczywiście mimo to, druga zasada termodynamiki nie jest naruszona [...]. s. 7 (biol.)

Przypuszcza się, że w procesie ewolucji powstały one przez endosymbiozę. s. 23 (biol.)

Rozwiązanie takie z pewnością musiało być korzystne, ponieważ [...] s. 26 (biol.)

Oczywiście reakcja musi być zawsze taka, aby niwelować skutki [...]. s. 33 (biol.)

O tego typu układach możemy mówić zarówno na poziomie komórkowym, jak i na poziomie wielokomórkowego organizmu. s. 33 (biol.)

Jednak warunkiem zajścia fosforylacji oksydatywnej jest oczywiście dostępność tlenu [...]. s. 38 (biol.)

Wstawiając [...] otrzymamy równanie kwadratowe, które oczywiście potrafimy rozwiązać [...]. s. 9 (fiz.)

Możemy sobie wyobrazić, że wędrujemy wzdłuż jakiejś krzywej [...]. s. 10 (fiz.)

Oczywiście po drodze zauważyliśmy, że [...]. s. 20 (fiz.)

Czasem zdarza się, że rysujemy na schematach sam wektor. s. 14 (fiz.)

6. Metatekstemy podkreślające ważność informacji

W tej grupie zamieszczone zostały metatekstemy podkreślające ważność przedstawianych informacji oraz usiłowania autora do zwrócenia uwagi odbiorcy na poszczególne wiadomości, np.:

Zauważmy, że operatory permutacji par w ogólności nie są przemienne. s. 8 (ch.k.)

Musimy zaznaczyć, że podane sposoby dowodzenia własności [...]. s. 13 (ch.k.)

Zauważmy ponadto, że [...]. s. 14 (ch.k.)

Zauważmy, że [...] s. 16, s. 18, s. 22, s. 23, s. 29, s. 30 (ch.k.)

[...] kolejność różniczkowania nie ma znaczenia. s. 18 (ch.k.)

W szczególności dla funkcji iloczynowej [...] uzyskuje postać [...]. s. 19 (ch.k.) 
Rozszerzenie bazy w stosunku do poprzedniej przestrzeni jest konieczne, aby można było tworzyć macierze zespolone. s. 24 (ch.k.)

Należy podkreślić, iż symetria funkcji falowej dotyczy cząstek [...]. s. 41 (ch.k.)

Bardzo istotną jego cechą, pozwalającą na tworzenie [...]. s. 9 (biol.)

Należy pamiętać, że w każdym organizmie żywym [...]. s. 10 (biol.)

Należy zwrócić uwagę, że w ten sposób powstaje układ [...]. s. 23 (biol.)

Należy podkreślić, że w mitochondriach [...]. s. 38 (biol.)

Chcemy zwrócić uwagę na to, że nie każde równanie [...]. s. 8 (fiz.)

UWAGA! Należy pamiętać, że równanie kwadratowe może mieć 2 rozwiązania. s. 9 (fiz.)

UWAGA 2! s. 9 (fiz.)

Należy jednak pamiętać, że to nie to samo [...]. s. 10 (fiz.)

Zauważmy, że jeżeli w ilorazie wprost wstawimy $\mathrm{x}=\mathrm{x} 0$, to [...]. s. 10 (fiz.)

Należy jednak pamiętać, że każdy z tych wzorów [...]. s. 11 (fiz.)

Pamiętamy, że granica ilorazu różnicowego [...]. s. 12 (fiz.)

[...] jest szczególnie ważna w fizyce, dlatego teraz poświęcimy jej trochę uwagi. s. 21

Ważne jest, aby pamiętać przy zamianie zmiennych, że [...]. s. 20 (fiz.)

Należy zawsze pamiętać, aby po funkcji f(x) [...]. s. 18 (fiz.)

[...], a jest to szczególnie ważne w przypadku funkcji wielu zmiennych [...]. s. 18 (fiz.)

Przypomnijmy, że w ten sposób obliczyliśmy objętość graniastosłupa [...]. s. 17 (fiz.)

Oczywiście wektor $\sim \mathrm{g}$ też ma punkt przyłożenia [...]. s. 14 (fiz.)

Ważne jest to, że wektor w fizyce jest zaczepiony do ciała, obiektu, punktu itd. s. 14 (fiz.)

\section{Wnioski}

Jak wynika z przeprowadzonej analizy skryptów nauk ścisłych, metatekstemy mają różnorodne i bardzo cenne funkcje, zarówno z punktu widzenia autora jak i czytelnika. We wszystkich trzech skryptach najczęściej pojawiają się operatory metatekstowe sygnalizujące relacje wewnątrztekstowe, anonsujące przebieg rozumowania autora a także dotyczące przeformułowań.

Środki wykorzystane przez naukowców pozwalają przede wszystkim na nawiązanie interakcji autora $\mathrm{z}$ odbiorcą, budując poczucie wspólnego analizowania poprzez użycie czasowników w 1 os. 1.mn. np. analizujemy, otrzymujemy, spójrzmy, zobaczmy itd. Za ich pomocą nadawca stara się ułatwić czytelnikowi zrozumienie jego myśli oraz ma możliwość 
wyjaśnienia przebiegu swojego rozumowania i przedstawienia kolejnych etapów w swojej pracy, a także ma możliwość odsyłania czytelnika do innych części tekstu, np. najpierw zanalizujemy, następnie przejdziemy do, teraz omówimy, $w$ rozdziale $X$ omówimy, $w$ poprzednim rozdziale była mowa o etc. W ten sposób konstrukcje te umożliwiają wprowadzenie porządku do tekstu, zachowanie chronologii oraz zasygnalizowanie odbiorcy toku rozumowania autora i kolejności, w jakiej informacje będą przedstawiane.

Służą one także stopniowaniu ważności i przydatności informacji, co stanowi cenną wskazówkę dla czytelnika oraz sygnalizują, na co powinien zwrócić szczególną uwagę, czytając tekst i rozwiązując ćwiczenia, np. zauważmy, uwaga, należy pamiętać, trzeba zwrócić uwage itd.

Metatekstemy pomagają integrować w tekście dane, przemyślenia oraz wykresy i różne materiały przygotowane przez innych autorów lub powoływać się na nie, odsyłając do źródeł, a także odwołać się do wspólnej wiedzy autora z czytelnikiem np. matematycy definiuja, dzięki pracom $X Y$, jak pisat XY, jak wiemy, jak wiadomo, stosować będziemy notację X, XY opart swój model, podstawowe założenia modelu XY, w myśl wzoru XY etc.

Dzięki nim autor jest w stanie przeformułować dane wypowiedzi, a także wyrazić swój stosunek do nich, potwierdzając ich słuszność lub poddając je w wątpliwość, np. prawdopodobnie, to oznacza, na przykład, innymi słowy, oczywiście, na pewno etc. Za pośrednictwem metatekstemów nadawca wyciąga wnioski i podsumowuje swoje badania, np. z równań wynika, w wyniku pomiaru otrzymamy, jest to przyczyna, można zauważyć, ciekawy wniosek wyplywa $z$, widzimy więc itd.

Jak wynika z naszej analizy, skrypty nauk ścisłych mimo swojej fachowości, zawierają znaczną liczbę środków metajęzykowych. Liczba oraz rodzaj użytych środków zależy od autora, ale we wszystkich trzech skryptach naukowcy starają się opisywać po kolei swoje kroki, nawiązując kontakt ze swoim odbiorcą oraz ułatwiając mu odbiór tekstu. Wszystkie trzy skrypty są nastawione na odbiorcę i mimo złożoności niektórych analiz, odbiór tekstu jest bardzo pozytywny. Reasumując, metatekstemy pełnią bardzo ważną funkcję w tekstach naukowych, a teksty inkrustowane tymi konstrukcjami są bardziej przyjazne w odbiorze $\mathrm{z}$ punktu widzenia czytelnika, dlatego, pisząc teksty, warto zwrócić na nie szczególną uwagę i korzystać z ich różnorodności.

\section{Bibliografia}

Austin, John (1962) How to do Things with Words. Oxford: Oxford University Press. 
Beck, Götz (1980) Sprechakte und Sprachfunktionen. Untersuchungen zur Handlungsstruktur der Sprache und ihren Grenzen. Tübingen: Niemeyer.

Danek, Danuta (1972) O polemice literackiej w powieści. Warszawa: PIW.

Dobrzyńska, Teresa (1991) „Tekst. Próba syntezy”. Pamiętnik Literacki 82 (2); 142-183.

Gajda, Stanisław (1982) Podstawy badań stylistycznych nad językiem naukowym. Wrocław: Państwowe Wydawnictwo Naukowe.

Gajewska, Urszula (2004) Metatekstemy w języku nauk ścisłych. Rzeszów: Wydawnictwo Uniwersytetu Rzeszowskiego.

Gizbert-Studnicki, Tomasz (1973) „Stwierdzenie jako akt mowy”. Studia Filozoficzne 3 (88); 83-97.

Gross, Harro (1998) Einführung in die germanistische Linguistik. München: Iudicium Verlag. Leclerc, Chantal (1999) Comprendre et construire les groupes. Saint-Nicolas: Les presses de l’Université Laval.

Lipczuk, Ryszard (2000) „O wielości i wieloznaczności terminów (na przykładzie klasyfikacji aktów mowy)”. Lingua ac Communitas 9; 169-76.

Lüdke, Jens (1984) Sprache und Interpretation. Semantik und Syntax reflexiver Strukturen im Französischen. Tübingen: Tübinger Beiträge zur Linguistik; 17-22.

Olszewska, Danuta (2007) Metatexteme in den Geisteswissenschaften, Gdańsk:

Wydawnictwo Uniwersytetu Gdańskiego.

Rosengren, Inger (1979) „Die Sprachhandlung als Mittel zum Zweck. Typen und Funktionen”. [W:] Inger Rosengren (red.) Sprache und Pragmatik. Lund: Lunder Symposium 1978; 188-213.

Searle, John R. (1977) Speech Acts. An Essay in the Philosophy of Language. London: Cambridge University Press.

Searle, John R. (1980) „Eine Klassifikation der Illokutionsakte”. [W:] Paul Kußmaul (red.) Sprechakttheorie. Wiesbaden: Athenaion; 82-108.

Weigand, Edda (1989) Sprache als Dialog. Sprechakttaxonomie und kommunikative Grammatik. Tübingen: Niemeyer.

Wunderlich, Dieter (1970) „Die Rolle der Pragmatik in der Linguistik”. Der Grammatik, Deutschunterricht 22 (4); 5-41.

Wunderlich, Dieter (1978) Studien zur Sprechakttheorie. Frankfurt/M: Suhrkamp Verl.

Wunderlich, Dieter (1986) „Wie kommen wir zu einer Typologie der Sprechakte”. Neuphilologische Mitteilungen 89 (4); 498-509. 
Zdunkiewicz, Dorota (1993) „Akty mowy”. [W:] Jerzy Bartmiński (red.) Współczesny język polski. Wrocław: Wiedza Powszechna; 259-269.

Skrypty:

Jerzmanowski, Andrzej, et al. (1999) Biologia/Biotechnologia Molekularna Roślin polski. Warszawa: Pracownia Biologii Molekularnej Roślin UW / IBB PAN. (biol.)

Rajchel, Łukasz (2020) Chemia kwantowa. Skrypt. Warszawa: Pracownia Biologii [pobrane z http://tiger.chem.uw.edu.pl/staff//rajchel/Skrypt.pdf. Data ostatniego dostępu: 20.09.2020]. (ch.k.)

Strzałka, Radosław (2020) Podstawy fizyki I. Skrypt. Kraków [pobrane z http://home.agh.edu.pl/ strzalka/files/Skrypt.pdf. Data ostatniego dostępu: 20.09.2020]. (fiz.) 